\title{
MĀUi ANd THE PEOPle Of ThE NORTH
}

\author{
Carwyn Jones*
}

This story was inspired by my participation in a workshop on Indigenous Legal Traditions held in Fort St John, British Columbia, Canada, in 2011. At that workshop, lawyers and legal academics worked collaboratively with elders and other members of the local region's Cree and Dene communities over several days to explore ways of reading and working with indigenous legal 'texts'. Though the workshop was necessarily tentative and exploratory, there were powerful learnings for all involved and I would like to acknowledge the generosity of the peoples of the Treaty Eight territory for sharing their stories with all of us who were privileged to participate.

"Pāpā, can we have a story about Māui tonight?"

"Of course. There are lots of stories about Māui. Which one do you want to hear? The one about him fishing up this island we live on?"

"Nah, we know how that one goes."

"How about the one where he slows down the sun?"

"We know that one too."

"What about the one where he gets the secret of fire from his great ancestress, Māhuika?"

"You tell us that one all the time! Aren't there any new stories about Māui?"

"You want a new story about Māui?"

"Yeah."

"A new story...let's see now...OK, how about this. This is a new story about Māui, one where we find Māui many, many years after his most famous adventures. But at a time when Māui was becoming restless again. Māui always craved excitement, adventure, and change. Not for him a quiet life, whiling away the hours, fishing, weaving or playing golf. In his day he had tamed the

Ngāti Kahungunu and Te Aitanga-ā-Māhaki, Lecturer, Faculty of Law, Victoria University of Wellington, and Co-Editor of the Māori Law Review. 
mighty sun itself! Even challenged the very mortality of human beings! Admittedly, that hadn't worked out as well as he had hoped, but it had been worth a try. Anyway, that was all a long time ago. He knew it was not his day anymore. Though surely he still had a few tricks up his sleeve, a few more adventures yet to be had. And there was still plenty that needed to be done. He saw many communities suffering great hardships. But where would he be of most use? Where could he use his powers to make real change in people's lives?"

"Then he remembered a place he'd heard people speak of - 'The Law' it was called. Some people said that The Law was the only place you could find justice. Others said that it was a site of oppression. Māui had heard many different things about The Law - that it was the location of a proud and ancient civilization, that it was an empty crumbling ruin, that it was a vibrant, dynamic and cosmopolitan place. So many different and contrasting views! But all the stories suggested that, for good or ill, The Law had a huge effect on the lives of people who had been there. Māui was intrigued. He decided he wanted to see The Law for himself."

"So, Māui set off for The Law. But it was not an easy journey. For a start, Māui wasn't exactly sure where The Law was. It wasn't clearly marked on any maps, though if he looked hard he could make out some smudged markings which gave him a general sense of where to look for The Law, but no more than that. Travellers he met along the way weren't much help either. Their directions were not especially precise and often Māui felt as though they were talking about completely different places."

"Just when he was on the verge of abandoning his journey, Māui caught a glimpse of a settlement off in the distance. Could this be The Law? As he came closer he began to appreciate the elaborate construction of this settlement. Some of the structures mirrored the natural environment the contours of the land, the progress of the waterways, the life-cycles of plant and animal life, the balance and inter-dependence of the natural world. Some buildings had a spiritual quality to them that he could not quite put his finger on. They were not like churches exactly, but he could sense they were imbued with the powers of the gods and the spirit world like awe-inspiring cathedrals or the intricacy of the carvings on the meeting-house in his own village. Other buildings had obviously been carefully and deliberately built by people for particular purposes - fortress-like structures to protect what was kept within, bridges that reached out to forge new relationships, high walls to set boundaries and prevent encroachment. And the wide streets and tree-lined avenues had obviously been designed to facilitate and encourage movement in some directions and to discourage or prevent movement in other directions. Māui marveled at the complexity of it all. Sure, there were some parts of town that looked as though they had developed in a slightly haphazard and chaotic fashion, but Māui felt that that all added to the charm of the place."

"As Māui rounded a corner in what seemed to be a slightly neglected area of town, he came across a large group of people huddled around a map and deep in conversation. He exchanged greetings and discovered the group had come from the North. Like him, they were interested in finding out as much as they could about The Law. They told him they had been here before. In 
fact, they were once very familiar with this place, but things had changed. Others had built over the top of the landmarks they used to navigate. When Māui looked at their map, he saw that it did not show the roads and streets of the settlement they were within, but there were clearly other paths, tracks, alleyways, promenades laid out which one could use to travel through The Law. Māui could see that following these pathways would show you very different aspects of The Law than you would see from the streets."

"Yet the group still seemed uncertain about how best to proceed. The issue seemed to be that not all the members of the group wanted to use the map. It wasn't as though anyone wanted to use the official roads and streets, but there was some concern that their map provided a very incomplete picture of the vast network of paths and tracks that crisscrossed The Law. Some of the guides amongst the group said that their methods of navigation could not be represented by lines or icons on a map. Others felt that it was unwise to follow a path on the map when the map could not show all of the connecting paths that link to places outside the boundaries of the map. Then, an elder rose to speak. The elder acknowledged the expertise of the guides and the importance of taking account of their concerns. But, the elder noted, the guides are not the only ones who ought to have a say in this matter. The map contained some useful information. And using the map might in fact help the community to re-connect with some of the matters the guides spoke of. Travelling the pathways on the map might encourage people to re-discover the connecting paths that were not represented on the map. Getting used to travelling through The Law once again might build the confidence of the group to use more widely the other navigational tools that are available to them."

"The group seemed persuaded by these arguments put forward by the elder and readied themselves to set off again. Māui farewelled the people from the North and continued on his own journey. After a short while, he reached the top of a rise from where he looked over the entire settlement. He could see the people from the North making their progress through The Law and, as they did so, Māui noticed something quite unexpected. As the group travelled through the settlement, they actually appeared to be changing the very landscape of the city itself. The shapes of the buildings were modified. The layout of the streets began to bend before his eyes to align more closely with the group's journey. Or was that just his eyes playing tricks on him? If it was, it was a good trick. He blinked, shook his head and started the long journey home."

"Is that the end?"

"Well, it is the end of one story, but also the beginning of others."

"Like the story of Māui's journey home?"

"Yes"

"And the story of the people of the North?"

"Yes" 
"And the story of The Law?"

"Maybe, yes."

"Will you tell us those stories one day?"

"I can tell you some of them, but you might have to help me figure out more endings and beginnings."

"We'll help you Pāpā."

"Ka pai, tamariki mā. Then they really will become your own stories."

"Our own stories, Pāpā."

"Ae, that's right. Our own stories." 